2012

\title{
How Open Innovation Affects the Drivers of Competitive Advantage
}

Richard Reed

Cleveland State University, r.reed68@csuohio.edu

Susan Storrud-Barnes

Cleveland State University, s.f.barnes@csuohio.edu

Len Jessup

Follow this and additional works at: https://engagedscholarship.csuohio.edu/bus_facpub

Part of the Business Administration, Management, and Operations Commons

How does access to this work benefit you? Let us know!

Publisher's Statement

This article is (c) Emerald Group Publishing and permission has been granted for this version to appear here: $10.1108 / 00251741211194877$. Emerald does not grant permission for this article to be further copied/distributed or hosted elsewhere without the express permission from Emerald Group Publishing Limited.

\section{Original Published Citation}

Reed, R., Storrud-Barnes, S., Jessup, L. (2012). How Open Innovation Affects the Drivers of Competitive Advantage. Management Decision, 50(1), pp. 58-73.

This Article is brought to you for free and open access by the Monte Ahuja College of Business at EngagedScholarship@CSU. It has been accepted for inclusion in Business Faculty Publications by an authorized administrator of EngagedScholarship@CSU. For more information, please contact library.es@csuohio.edu. 


\title{
How open innovation affects the drivers of competitive advantage Trading the benefits of IP creation and ownership for free invention
}

\author{
Richard Reed and Susan Storrud-Barnes \\ Cleveland State University, Cleveland, Ohio, USA, and \\ Len Jessup \\ Eller College of Management, University of Arizona, Tucson, Arizona, USA
}

\begin{abstract}
Purpose - This paper aims to explore how community-controlled open innovation affects cost- and differentiation-based competitive advantage, and to explain how it allows some sources of economic rent to remain while others are taken away. Although models of competitive-advantage remain relevant, open innovation means that the main drivers of performance are changed. Open innovation means that there are implications for firms' ability to profit from intellectual property that they do not own. The paper seeks to address those issues.

Design/methodology/approach - The work is conceptual.

Findings - Economic rents from property rights disappear, those from economies of scale and capital requirements are reduced, but those from experience-curve effects, differentiation, distribution, and switching costs remain. Similarly, rents from the difficult-to-imitate resources of networks and reputation remain intact, and while those from employee knowhow and culture remain, they are likely to be in reduced amounts.

Research limitations/implications - Propositions are provided for empirical testing. There also is a need to identify breakpoints between open-innovation benefits and the costs associated with lost innovation skills, and a need to extend this work to firm-controlled and third-party controlled open innovation.

Practical implications - For some firms open innovation will not adversely affect competitive advantage but those whose advantage is driven by barriers to entry, skills in innovation and anticipating customer needs, or that rely on proprietary product designs, can lose in the longer term.

Originality/value - Where the majority of work examining open innovation addresses property rights, economic rationales, governance, and processes, this work focuses on the effects of open innovation on strategy content and consequent firm performance.
\end{abstract}

Keywords Open innovation, Competitive advantage, Economic rents, Innovation

Paper type Conceptual paper

\section{Introduction}

Sawhney and Prandelli (2000) are generally credited with originating the term open innovation but, since then, Chesbrough's (2003a) seminal work moved the concept on to include a variety of ways to capitalize on innovations both externally and internally. He saw open innovation as a paradigm shift from creating and hoarding innovations internally to accessing and integrating external knowledge. The latter is based on one of his key principals of "not all the smart people work for us." That sentiment has been taken to heart by Procter and Gamble who now get over half of their innovations from 
outside sources. For example, one of Procter and Gamble's best selling products, the Spinbrush, a battery operated electric toothbrush, was developed by four entrepreneurs in Cleveland, Ohio (Chesbrough, 2003b). In addition to finding revenue-generating innovations, open innovation has had the added benefit of improving Procter and Gamble's R\&D efficiency (RTM, 2007). Chesbrough foresaw that open innovation can eliminate innovation costs altogether, but that it constitutes a two-edged sword because, by eliminating the cost of innovation, it also removes a barrier to new competition. That, plus other concerns have emerged with the increase in open innovation; for example, there is the risk of loss of innovation skills, the costs of coordination can be high, and being able to generate profits is uncertain (Enkel et al., 2009). The latter continues to be a topic of significant interest in both the business press and trade journals (for example, see Collins, 2007; Hamm, 2007; Howe, 2006; Lamarca, 2006), but has not received nearly as much academic attention. Consequently, in this work we explore how open innovation affects firms' abilities to generate and capture the economic rents that accompany the competitive advantage that comes from controlling the intellectual property that underpins innovations.

Open-innovation takes three main forms: firm controlled, third-party controlled, and community controlled. For example, for firm controlled, Siemens has its own web site that solicits innovations, as do other companies like the Crown Packing Technology. Third-party sites, such as InnoCentive.com, which was developed by Eli Lilly and is also now used by firms like Boeing and Dupont, typically provide a way for firms to post problems so that individuals or organizations can provide a solution and receive a monetary reward (Howe, 2006). The final category of community-controlled sites includes Elphel, Neuros OSD, Open EEG, Openpandora, Oscar, OSGV, and RepRap (Abdelkafi et al., 2009; Raasch et al., 2009), among others. Elphel designs high-performance cameras, Open EEG designs devices to capture neuron feedback from the brain, Openpandora developed a pocket gamer (now in production), Oscar is designing a world car with sustainable mobility, OSGV is developing a seven-passenger SUV with various fuel options, and RepRap is developing self-replicating 3D printers. These communities can be small (seven people started Openpandora and 15 people developed the Free Beer community) to very large (an estimated 30,000 in Neuros OSD), and the innovations that emerge from them can include new technologies, product improvements, or new product designs. Although this form of open innovation has received less attention than the other two forms, it is important because the control of the intellectual property is outside the boundaries of any firms wanting to use it (see Ulhoi, 2004). This lack of control of intellectual property provides a more-stringent test of the models that have served strategic management well in the past and, consequently, we focus on this form of open innovation in this work.

Raasch et al.' (2009) interviews with executives revealed that deriving a profit from open and easily imitable designs is counterintuitive. So, in this work, we seek to determine how established thinking on business-level strategy and competitive advantage is affected by open innovation. Thus, our level of analysis is the firm and, specifically, strategy and performance at the business level. Although some non-profit organizations have been using open innovation, here, we are assuming the existence of a profit motive. 


\section{Competitive advantage and economic rents}

Monopoly rents arise from barriers to competition and barriers to entry that prohibit potential competitors from satisfying excess demand. The lists of what constitutes these barriers are numerous, overlapping, and long established in the literature: Bain $(1954,1956)$ identified scale and capital requirements as determinants of entry and, in his book on Barriers to New Competition, he also emphasized the importance of product differentiation and absolute cost advantage. Since then, scholars also have focused on experience-curve effects, capital requirements, customer switching-costs, access to distribution channels, property rights, and other cost advantages independent of scale as being sources of barriers to entry (e.g. Karakaya and Stahl, 1989; Lieberman, 1987; Porter, 1980). Synthesizing these, we bound our study and focus on scale, experience effects, capital requirements, product differentiation, distribution, and switching costs. Given the nature of this work, we separate out property rights.

Ricardian rents arise from owning scarce and valuable resources (see Mahoney and Pandian, 1992; Peteraf, 1993). For example, firms can capitalize on things like a good reputation because market failure means that such resources cannot be purchased in factor markets by competitors. Similar to the lists for sources of monopoly rents, there exist numerous lists of the sources of Ricardian rents. They include resources that are valuable, rare, and difficult to imitate; durable resources that are not readily transparent, transferable, or replicable by competitors; and resources that are heterogenous among firms and are imperfectly mobile and imperfectly imitable (Barney, 1991; Grant, 1991; Peteraf, 1993). However, it was Hall's $(1992,1993)$ grounded research that identified the intangible resources of reputation, employee knowhow, culture, networks, and databases as being the main sources of sustainable advantage, which we focus on here as the key drivers of Ricardian rents.

A third type of rents associated with innovation, entrepreneurial rents, are naturally self-destructive because, with patenting or bringing-to-market a new product or service, the underlying knowledge is revealed. Given that open innovation automatically diffuses knowledge, entrepreneurial rents will not exist. That does not mean that with open-innovation entrepreneurial activity cannot exist. Instead, it simply means that open innovation removes the need to reverse-engineer products or circumvent patents. Thus, we restrict our discussion to monopoly and Ricardian rents. The pairing of those with the fundamental drivers of competitive advantage - cost and differentiation - provides an organizing framework for the rest of our discussions on open innovation. That framework and the outcomes of the following discussions are summarized in Figure 1.

\section{Cost-based advantage and monopoly rents}

Open innovation allows monopoly rents from economies of scale, experience-curve effects, and capital requirements. Marshall (1967) defined economies of scale as "the advantages created within the plant or firm, by reason of the increase in the scale of the plant's production or of the firm's operation." Stated more broadly, cost savings are available from efficiencies as the firm increases its size. Even when adopting open-innovation designs for new products, Lego still benefits from its scale effects in production and distribution, as does Procter and Gamble with the open innovations it elects to commercialize. In addition to the obvious scale benefits in operations and administration, there are other benefits that accrue to larger firms. For example, 


\begin{tabular}{|c|c|c|}
\hline & Monopoly Rents & Ricardian Rents \\
\hline Cost & $\begin{array}{l}\text { Allows: } \\
\text { Rents from barriers to entry from } \\
\text { economies of scale in such areas as } \\
\text { operations, and from experience- } \\
\text { curve effects in operations and } \\
\text { knowledge management } \\
\text { Takes Away: } \\
\text { Rents from barriers to entry from } \\
\text { scale benefits in innovation, and } \\
\text { access to and the cost of capital }\end{array}$ & $\begin{array}{l}\text { Allows: } \\
\text { Rents from employee know-how in } \\
\text { such areas as operations, from } \\
\text { organization culture, and from the } \\
\text { network relationships with leaders } \\
\text { in the open-innovation community } \\
\text { Takes Away: } \\
\text { Rents from the ability to capitalize } \\
\text { on innovation synergies from } \\
\text { R\&D spillovers and the } \\
\text { interaction between internal and } \\
\text { external sources of innovation }\end{array}$ \\
\hline Differentiation & $\begin{array}{l}\text { Allows: } \\
\text { Rents from product differentiation, } \\
\text { distribution-channel control, and } \\
\text { customer switching costs } \\
\text { Takes Away: } \\
\text { Rents from proprietary product } \\
\text { design }\end{array}$ & $\begin{array}{l}\text { Allows: } \\
\text { Rents from firm reputation, } \\
\text { employee knowhow in such areas } \\
\text { as operations, and organization } \\
\text { culture } \\
\text { Takes Away: } \\
\text { Rents from employee know-how } \\
\text { and a culture that anticipates } \\
\text { customer needs }\end{array}$ \\
\hline
\end{tabular}

research has revealed that firms with larger numbers of employees are better able to capitalize on knowledge and knowledge spillovers (Macher and Boerner, 2006). The benefits of specialization and standardization in operations and administration are firm-specific, as are the benefits of knowledge spillovers. All of these are sources of barriers to entry and, therefore, monopoly rents should continue to be available regardless of the source of innovation.

Similarly, we can conceive of no reason why the source of innovation should affect monopoly rents from experience-curve effects in things like production. Each time Procter and Gamble doubles output of the Swiffer ${ }^{(\mathcal{O}}$ duster (an external innovation) its production costs can be reduced by a set amount. Additionally, because open-innovation tends to be an internet phenomenon, the associated technology may improve the potential for rents from experience curves in other areas. Amit and Zott (2001) examined value creation in $e$-business and developed theory explaining how transaction efficiencies are available, not only for the customer but also for firms. They identified benefits from the interconnectivity that are available with virtual markets, faster decision making (information is more readily available), streamlined inventory control and supply-chain management, reduced marketing and sales costs, and better scalability which, by scaling up, allows scale effects from increased numbers of customer transactions. Relatedly, the work by Macher and Boerner (2006) revealed
Figure 1.

What open innovation allows and takes away 
that, in business on the internet, there are benefits to be gained from the skills required for managing information and knowledge insofar as those skills (and associated systems) can be honed to further reduce costs. In other words, experience effects exist in managing knowledge. For example, BT, the telecommunications operator, has been able to capitalize on externally-designed web interfaces because of the skills of its own software engineers (Bughin et al., 2008). Additionally, Macher and Boerner found that experience in knowledge management has a particularly strong effect on performance when combined with economies of scope, and they observed that employees' ability to take ideas from one area and apply them in related areas increased with the experience that firms had at working with knowledge. Their results showed that participating in a wide array of research projects did not in itself improve knowledge utilization and performance (in fact, it had a detrimental effect on performance), but when combined with experience, the effect was positive. That means that the ability to tap into the knowledge of the people who make up an open-innovation community, and then be able to manage it internally, will create barriers that make it difficult for new entrants successfully to enter an industry.

It long has been recognized that large capital requirements and access to lower-cost capital create barriers to entry (Bain, 1956). The rationale for that is readily apparent and does not need belaboring here. Suffice it to say that regardless of the source of an innovation, large capital requirements for the purchase of, say, capital equipment, still create a barrier to entry. However, as discussed below, the nature of internet-based open innovation means that some of the cost-of-capital barriers are reduced.

Open innovation takes away some barriers from scale and some barriers from the cost of capital. The majority of thinking on economies of scale was developed before computers, the internet, and the emergence of open innovation. While that does not invalidate the underlying logic of barriers to entry from scale, particularly in terms of things like production, it has been recognized that the internet makes markets more contestable by, for example, providing equal visibility to all, regardless of size (Goel and Hsieh, 2002; also see Porter, 2001). That logic also applies to open innovation because, as already noted, all firms can benefit from no innovation costs, regardless of size; i.e. no-cost innovation eliminates the need to amortize innovation costs across large production-runs. For example, Threadless, the shirt retailer that gets its designs from, and sells to, on-line customers, has expanded to the point of being able to open a physical store in Chicago (Bughin et al., 2008).

From surveys of executives it has been determined that, after cost advantages of incumbent firms, capital requirements are the next most important barrier to entry (Karakaya and Stahl, 1989; Karakaya, 2002). Although the effects of the reduction in barriers from capital requirements may not be as dramatic as the elimination of product-development costs from open innovation, they still have a negative effect on monopoly rents. One of the benefits of firm size is a reduced likelihood of default on debt, which means that the access to capital is easier and the costs of borrowing are reduced. That conventional view is being changed by the internet and, as already noted, open innovation is primarily an internet-based phenomenon. While capital-market access remains rooted in the relationship that financial institutions develop with the client, the internet has reduced those barriers to entry (Kandampully, 2003). As individuals in open-innovation communities recognize the value of an innovation, they can be made aware of the financial needs of the organization and may 
then be willing to risk their own money by providing financing. They will become informal or angel investors and, as Steier and Greenwood (2000) found for open-source software (e.g. Apache, Linux) such investors can "represent a significant source of venture capital." This leads to:

P1. Whereas monopoly rents from experience-curve effects should remain intact, those from economies of scale and capital requirements will be reduced by open innovation. Specifically, rents from barriers to entry will be reduced as market contestability increases due to the reduced costs of innovation, and from access to non-traditional sources of capital and the consequent reduced costs of capital.

\section{Cost-based advantage and Ricardian rents}

Open innovation allows some rents from employee know-how, culture, and networks. Hall's (1993) study revealed that employee knowhow was rated by managers as one of the most "durable" and "important contributors to business success." It includes the tacit skills and knowledge that make imitation difficult. In addition to the usual operational and administrative skills that underpin advantage, there also is knowhow on the integration of the internet and its tools into the business model - it has changed the way firms communicate with customers, sell their products, and manage their supply chain. Similarly, for open innovation, there is a need for know-how in working with (and not alienating) individuals in the open-innovation community. Nokia is working on a culture change to incorporate the open-innovation process and, where Whirlpool uses a more-gradual, stepwise approach to open innovation, IBM threw open the internet doors to employees and the public in what it termed an "innovation jam" (Collins, 2007)[1]. Clearly, there is no single template for developing the know-how necessary for managing open innovation but, once achieved, it becomes a valuable resource.

Hall (1993) reported that the managers in his survey ranked culture as the most important resource after employee know-how and product and company reputation. He found that the valuable components of culture included the "ability to manage change, ability to innovate, team-working ability, participative management style, perception of high quality standards, [and] perceptions of high standards of customer service" (Hall, 1993, p. 617). Assuming managers' perceptions of value remain constant, a culture that lends itself to embracing and incorporating the change that is occurring with the use of open innovation will provide an advantage over firms where there is resistance to such change. Such a change has been implemented at Procter and Gamble with their open-innovation program called Connect and Develop. The program has moved the culture from one that was insular and shunned products that were not developed in-house to one that now incorporates product ideas that were "Proudly found elsewhere" (RTM, 2007). Barney (1986) noted that cultures that are valuable, rare, and difficult to imitate will confer an advantage. He also noted that many cultures are easy to imitate and, thus, are not rare. Given the difficulty that many firms have coping with change, particularly overcoming the "not-invented-here syndrome", we can deduce for cultures that value and embrace externally-generated innovations, that the former condition of inimitability will hold true rather than the latter. Within the context of working with open-innovation communities, that will then become a source of cost-based Ricardian rents. 
People in the open-innovation community likely will be willing freely to contribute time to innovations where their input is welcomed. Volkswagen draws on ideas from a community of Golf GTI enthusiasts and, as work by Fuller et al. (2008) showed, when their ideas are welcomed, it has a positive impact on their willingness to be involved in open innovation projects. Extending that, it is likely that there are additional benefits insofar as the simple act of participating and being able to contribute should help in retaining the goodwill of the open-innovation community. Not only should goodwill lead to more cooperation in the innovation process, reducing costs even more, but it may also mean that more innovations will be forthcoming. In short, if managed well by the firm, there is a "feel-good" effect for members of the open-innovation community that is self-reinforcing. Managing the process well means that the skills embodied in team-working abilities and participative management are complementary to what is happening in the open-innovation community, which, in turn, should lead to more rents in the form of even greater difficult-to-imitate efficiency.

Networks - the human relations that transcend the requirements of organization and commercial relationships - have become a favorite research topic in management, whether they are at the level of the organization or the individual[2]. It is the latter that is of relevance here because open innovation means that it is individuals, albeit in a community, with whom the firm has to work. The VP for Innovation at Procter and Gamble explained: "When you're inventing within your own walls and boundaries, you have a lot of positional power - command and control is hierarchical. But when you're leveraging people whom you don't have direct control over, you have to build relationships and trust" (RTM, 2007). Those relationships and trust are particularly important in the case of open-innovation community leaders. Research has revealed that open-innovation community leaders not only have the required technical skills, they also have the ability to encourage the volunteers to coalesce behind a common goal (Fleming and Waguespack, 2007). Given that both managerial and innovation performance are products of managers' micro-social processes within networks and the consequent variety of knowledge to which managers are exposed, we may expect that there should be the opportunity for accessing and recombining knowledge held by these leaders and elites in the open-innovation community that will help reduce costs of both organization and operation[3]. Therefore, the network of contacts and relationships with individuals also should constitute a rent-generating resource.

Databases were a resource that managers in Hall's (1993) study perceived as being important for sustaining competitive advantage. However, even as Hall was conducting his research, the use of relational databases (e.g. SQL Server, Oracle, DB2) was becoming common-place in business. The next generation of information technology, the one that is replacing those legacy databases and also now is starting to become prevalent in large organizations, is enterprise-planning software (e.g. SAP, PeopleSoft/Oracle). The software contains customized databases that facilitate the integration of manufacturing, marketing, accounting, and so forth, to improve efficiency in the process of creating and delivering goods to customers. As yet, and as far as we are aware, no software includes the facility for integrating open innovation into the database. Should that ever occur, the software will provide an advantage to those organizations that purchase it, but the advantage will be temporary as other organizations are able to purchase it and re-level the playing field. We thus set aside the use of databases as a source of Ricardian rents. 
Open innovation takes away some of the value of employee knowhow on firm-generated innovation. Enkel and colleagues noted that too much openness may not be a good thing for the longer-term because it can erode core (innovation) competencies (Enkel et al., 2009). Those competencies, which are embedded within R\&D activities, organizational routines, and organization culture are required for capitalizing on innovations procured externally (Veugelers, 1997). The longer-term cost manifests itself in lost synergy gains from the interaction with external sources of innovation and the consequent spillover that ends up as new innovations that, otherwise, would not have been recognized. Research (e.g. Audretsch and Keilbach, 2007) has shown that situations that are knowledge impoverished generate fewer spillover entrepreneurial-opportunities than those that are not.

Whether or not open innovation will completely replace traditional approaches to innovation is difficult to predict but, as open innovation gains strength, and as firms strive to compete with others that have adopted open innovation, the emphasis on traditional approaches likely will decline because the open-innovation community works for free. Even though some managers, like those at Procter and Gamble, are keenly aware of the importance of retaining a strong internal R\&D function, managers who are under pressure to improve returns in the short-term may reduce spending on internal innovation (RTM, 2007). In short, the knowhow associated with these conventional approaches to innovation will deteriorate as innovation skills, absorptive capacity, and the organizational routines that produce the ability to innovate are diminished or lost. For example, Boeing has long realized that when it comes to innovation, you "use it or lose it" (Gunter, 2002). That not only means that revenue potential is lost but also that the average cost of innovation is higher than it otherwise would be. Thus:

P2. Whereas cost-based Ricardian rents from organization culture and networks should remain intact, those from employee knowhow will be reduced by open innovation. Specifically, as firms rely more on open innovation, their ability to innovate using traditional internal sources will diminish and the opportunity costs of missed chances for innovation synergies and spillovers will increase.

\section{Differentiation-based advantage and monopoly rents}

Open innovation allows monopoly rents to be extracted from product differentiation and customer switching costs. Differentiation arises from several sources and, as Karakaya and Stahl (1989, p. 85) state:

Established firms have brand identification and customer loyalties stemming from past advertising, customer service, product differences, or simply being first into the market.

Clearly, the idea of differentiation creating a barrier to entry is heavily influenced by traditional views on marketing but, with open innovation, marketing requirements likely will change. Some firms already have learned that lesson. As already mentioned, Volkswagen has tapped into the Golf-GTI community for innovations, and Ducati, Harley Davidson, and Nike have capitalized on innovations suggested by their own communities (Fuller et al., 2008). At Niketalk community members created new features for basketball shoes that they want, and presumably value, which means that they are perfectly differentiated. Per conventional wisdom, increased differentiation means higher barriers to entry and, thus, increased monopoly rents. 
Amit and Zott (2001, p. 508) explained how, among other things, $e$-businesses find "new ways of conducting and aligning commercial transactions ... [and] creating value by connecting previously unconnected parties, eliminating inefficiencies in the buying and selling process through adopting innovative transaction methods, capturing latent customer needs (such as haggle-free car purchasing from the convenience of your home), and/or by creating entirely new markets (e.g., auctions for low-ticket items)." As open innovation becomes more widespread and an accepted way for companies to do business, open-innovation communities, being driven by self-interest, likely will identify even more links, connections, methods of transaction, and latent markets to serve even more of their needs (i.e. they will create even more opportunities for differentiation). In turn, word-of-mouth recommendations within open-innovation communities take on a new importance as online-community members proselytize products to others (Fuller et al., 2008).

Switching costs are the costs incurred when a buyer switches from one supplier's product to another's. However, even when switching costs exist, it does not mean that firms using open innovation cannot coexist with businesses using traditional approaches to innovation. For example, as we have witnessed for open sourcing of software, Linux and Microsoft coexist, and we now are witnessing the coexistence of goods developed through open innovation by organizations like the Whirlpool with more-traditionally developed offerings (Collins, 2007). If the firm using open innovation is first to market then the second entrant needs a constant source of new customers or existing customers that are willing to switch, which means that the good has to provide significant benefits above and beyond the cost of switching. If the open-innovation product is second to the market, then it faces the same problems. Beyond that no-effect scenario, open innovation can lead to increased switching costs because, as Amit and Zott (2001) noted, existing views on resource-based theory include the concept of complementarity among assets as a source of value creation, and they go on to explain how value can be created by bundling complementary products. Because bundling provides efficiencies for customers, and because people are nothing if not self serving, it is likely that open-innovation communities will tend to produce innovations incorporating bundles of goods. The bundles and efficiencies they desire creates increased differentiation which means they also will incur increased switching costs. Therefore, barriers competition and new entry, and the consequent rents from switching costs should, at a minimum, continue to be available with open innovation.

Conventional wisdom (e.g. Porter, 1980) also holds that the importance of channels of distribution for creating monopoly rents comes from the barriers to new entry that arise either when incumbents control channels (e.g. the industry is vertically integrated), or when distributors are satisfied with the products and services provided by established firms. The underlying rationale was pre-internet and clearly based on the distribution of products through resellers. Today, there are competing views on what has happened to the benefits of channel control. First, favorable word-of-mouth in online communities about the service provided by a distributor allows the distribution channel to retain its barrier-to-entry properties (Flavian and Guinaliu, 2005). Second, it has been argued that the technology reduces the power of wholesalers and retailers insofar as it allows customers to deal directly with suppliers, which eliminates the need for "middlemen" (Porter, 2001). Either way, the effect is a reinforcing of the barriers. Such is particularly the case with firms dealing with open-innovation communities. 
Contact with community members is established prior to any sale and, assuming that members of the open-innovation community have an interest in purchasing a product they have helped develop, that contact allows the firm sell the product directly. Some firms (e.g. Threadless and Muji) have taken that one step further by getting preorders from the innovating communities they work with prior to any production (Bughin et al., 2008; Ogawa and Pillar, 2006).

Open innovation takes away the barriers created by traditional means of protecting property rights and from the control of distribution channels. Given that we primarily are concerned with the effect on firms using innovations where the intellectual property remains under the control of the open-innovation community, or the community makes it free to all, patents and secrecy are not available to the firm. Therefore, in short, no control over the intellectual property effectively eliminates that potential for monopoly rents. Therefore:

P3. Whereas monopoly rents from differentiation, distribution-channel control, and customer-switching costs should remain intact, those from the possession of intellectual property will be reduced by open innovation. Specifically, as firms rely more on open innovation, rents from barriers to entry from proprietary intellectual property will be reduced.

\section{Differentiation-based advantage and Ricardian rents}

Open innovation allows firms to continue to benefit from reputation, employee knowhow, and organization culture. In Hall's (1993) survey, managers rated reputation as being a major contributor to sustainable advantage. Their judgment is supported by an array of research that confirms the existence and validity of the link between reputation and firm performance (e.g. Black et al., 2000; Graham and Bansal, 2007; Gregory, 1998). A good reputation is a resource that is valuable and difficult to imitate and, although it easily can be damaged, it also can be durable (Carter and Ruefli, 2006). Thus, fitting with the resource-based view, it is an intangible resource that can be a source of Ricardian rents - customers are willing to pay a premium for goods from firms with a superior reputation - and that condition should hold regardless of the source of an innovation. Hall (1993, p. 616) stated:

The emphasis placed on this resource by CEOs suggests that a key task of management is to make sure that every employee is disposed to be both a promoter and a custodian of the reputation of the organization ...

That notion extends to members of the open-innovation community. Clearly, as the Senior VP for R\&D and the VP for Innovation at Procter and Gamble recognized, members of innovation communities are not employees but, because of their involvement in the innovation process, there is the potential for an affinity with the created product and its producer (RTM, 2007). Those contributing to open-innovation projects are likely to take ownership of the product they have helped create, which means they likely will recommend it to others (see Wind, 2006, who argued that people become advocates for companies and recommend goods and services to others).

Amit and Zott (2001) identified a concept of "lock-in" for e-businesses, and it applies here. They noted how lock-in arises from resources such as brand name and trust. In their research on the Volkswagen community, Fuller et al. (2008) found that brand passion led to brand trust which, in turn, led to active participation in open-innovation 
projects. Thus, under conditions of open innovation, firm brand - and we also include reputation - remain a valuable and difficult-to-imitate resource, which means they can be a source of Ricardian rents. Amit and Zott (2001, p. 507) also explained that the interactions between community members become "network generators" as one member of the network has "an effect on the production or utility function of other participants in the network... and e-business operations can be designed to harness the power of this lock-in mechanism." In short, branding (and reputation) take on a new importance when open innovation is introduced into the process of creating and producing goods, and its rent-generating potential should thus remain intact.

Hall's (1993) study identified perceptions of high quality and perceptions of high customer service as being important parts of culture that contributed to sustained advantage. Within the extensive literature on quality management there are no dissenting voices on the importance of top-management commitment to quality, the creation of a supportive culture, and the importance of employee education and training for being able to deliver quality. Similarly, on customer service, both the organization-behavior and marketing literatures have emphasized climate and culture as important mechanisms for employee guidance[4]. We already noted that Hall reported that managers ranked culture as the most important resource after employee knowhow and product and company reputation, and we explained how Procter and Gamble has adjusted their culture to better work with open-innovation communities. And, coming full circle, there clearly exists a relationship between a culture of quality and customer service and branding and reputation. So, in terms of open innovation, we can deduce that culture also is a source of rents.

Open innovation takes away some employee know-how and some benefits of organization culture. Employee know-how is valuable not only in terms of improving operational efficiencies, but also in being the cornerstone of anticipating customer needs. Customer intimacy is one of the things that helps firms to create value for which customers are willing to pay. In their study of market leaders, Treacy and Wiersema (1995, p. xv) noted that:

Customer-intimate companies do not pursue one-time transactions; they cultivate relationships. They specialize in satisfying unique needs, which often only they, by virtue of their close relationship with - and intimate knowledge of - the customer recognize.

They also explain that intimate knowledge goes beyond developing a relationship with the customer to include "breakthrough insights" that permit the identification of "total solutions" to customers' needs. While this ability to identify unrealized customer needs is rooted in employee knowhow, the desire to identify such needs and to commercialize them is driven by organization culture (see Mitsch's, 1990, discussion of 3M).

As previously noted, as firms rely more on open innovation, the ability to innovate may well diminish or be lost altogether. Not only will design skills be lost, but employees will not acquire the knowledge required to be able to create what customers do not know they need, nor will they be driven by the tradition of translating those needs into commercial goods. The danger of relying solely on open innovation already has been recognized by managers at Proctor and Gamble (RTM, 2007). Thus, firms' ability to separate themselves consistently from other companies by producing the products that spawn new markets will be reduced, as will the availability of Ricardian rents: 
P4. Whereas differentiation-based Ricardian rents from reputation should remain intact, those from employee knowhow and organization culture will be reduced by open innovation. Specifically, as firms rely more on open innovation, rents from the ability to anticipate customer needs will be reduced.

\section{Discussion}

Openness to new ideas from the environment improves firms' innovation performance. Laursten and Salter (2006) found that as the breadth and depth of searching using external actors and sources increased, so did innovation, and that while too much searching led to diseconomies and performance deterioration, openness to new ideas from the environment is superior to a closed, in-house, internal focus on innovation. Consequently, more and more firms are finding value by tapping into the ideas of online, open-innovation communities. In this work we have explored what happens to the drivers of competitive advantage and consequent economic rents when firms use innovations from communities that are not firm sponsored and not sponsored by a third party. We deduced that open innovation modifies the sources of monopoly rents for industry incumbents from barriers to entry: while rents from property rights disappear, and those from economies of scale and capital requirements will be reduced, those from experience-curve effects, differentiation, distribution, and switching costs will remain. Similarly, Ricardian rents from the valuable and difficult-to-imitate resources of networks and reputation should remain intact, and while those from employee knowhow and culture will remain, they will be in reduced amounts. Some of those monopoly and Ricardian rents that remain available may, however, take on the form of the shorter-lived quasi rents as things like product differentiation becomes easier to imitate because these community-led innovation groups make technology and designs freely available. That means that things like firm reputation become even more important for sustaining rents. Synthesizing these conclusions, we can deduce that while many of the fundamentals of our existing models of strategy still work in the face of this new source of innovation, the way we view and use them will have to be adjusted. That means adjusting, rather than abandoning, our dominant paradigm and rethinking some of our research questions.

There is a tradeoff between the benefits of open innovation and the benefits of internally-generated innovation. That raises the question: at what point do the benefits of reduced innovation costs from open innovation stop outweighing the increases in costs that come from lost scale and synergy effects in innovation, from reduced abilities to anticipate customer needs, and from not being able to eliminate or control competition by owning the intellectual property that surrounds an innovation? We have focused on community-controlled open innovation because it provided a more stringent test of the drivers of competitive-advantage, but the other forms of open innovation - firm controlled, third-party controlled - also need to be assessed for their impact on competitive advantage. It may be that equifinality exists among the different forms when matched with differing firm innovation skills and cultures, but that needs to be confirmed through empirical research.

There are numerous contingencies that also need to be incorporated as we move forward with both theory and empirical testing. For example, here we implicitly held constant the type of innovation - radical versus incremental innovation, architectural versus component, or competence-enhancing versus competence-destroying innovation. We held constant the effects of network externalities and the installed 
base which, in varying degrees, have implications for both monopoly and Ricardian rents. Further, having managed to access an open-innovation community, and assuming that, as described, there are rents available, the question becomes can the firm appropriate them? Grant (1991) explained how the appropriation of rents can be difficult if the resources that created them are vested in the skills of an individual. The "elite" members of innovating communities have power and may be able to bargain with the firm for special deals (preferential prices, payments, perquisites) that erode rents. In other words, they may behave like powerful employees and appropriate rents. If the firm does not provide what are deemed to be adequate discounts or perquisites, and because the organization has no control over them, they can stop cooperating and encourage less elite members of the community to do the same. This scenario fits closely with Amit and Zott's (2001) observation that peer recommendations have a downside because they can turn into a "dangerous downward spiral".

In terms of the implications for practice, we can deduce that firms whose competitive advantage is driven by experience-curve effects and employee knowhow in operations can capitalize on the benefits of open innovation with little risk of losing advantage. Similarly, the risk is limited for those whose advantage comes from differentiation, distribution-channel control, switching costs, and reputation. However, firms whose competitive advantage is driven by barriers to industry entry, existing innovation abilities that drive synergies in capitalizing on external innovation and in spillovers, that depend on their innovation skills for anticipating their customers' needs, or that rely on proprietary product-designs, risk losing advantage by using open innovation.

Clearly, there are risks associated with the use of open innovation. However, not using open innovation may be even riskier. Although research on the phenomenon of open innovation continues to gather momentum, there is much that is yet to be done. In this work we have provided insight into the effects on the drivers of competitive advantage. The next stage is to take this thinking on content and to interpret it into models of process that can be translated into normative recipes to guide firms in the quest to capitalize on the open-innovation phenomenon.

\section{Notes}

1. Collins (2007) also linked Whirlpool's use of open innovation with its return to profit growth.

2. This definition of networks is from Hall (1993). As noted, research on networks is extensive. Examples of research at the level of organization includes work by Echols and Tsai (2005); Schilling and Phelps (2007); Tsai (2001). At the level of the individual it includes work by Nooteboom (2000); Rodan and Galunic (2004).

3. This argument is based on the findings of Rodan and Galunic (2004).

4. This observation on the commonality between the literatures was made by Bowen (1990).

\section{References}

Abdelkafi, N., Blecker, T. and Raasch, C. (2009), "From open source in the digital to the physical world: a smooth transfer?”, Management Decision, Vol. 47, pp. 1610-32.

Amit, R. and Zott, C. (2001), "Value creation in e-business", Strategic Management Journal, Vol. 22, pp. 493-520.

Audretsch, D.B. and Keilbach, M. (2007), “The theory of knowledge spillover entrepreneurship”, Journal of Management Studies, Vol. 44, pp. 1242-54. 
Bain, J.S. (1954), "Economies of scale, concentration, and the condition of entry in twenty manufacturing industries", American Economic Review, Vol. 44, pp. 15-39.

Bain, J.S. (1956), Barriers to New Competition, Harvard University Press, Cambridge, MA.

Barney, J.B. (1986), "Organizational culture: can it be a source of sustained competitive advantage", Academy of Management Review, Vol. 11, pp. 656-65.

Barney, J.B. (1991), "Firm resources and sustained competitive advantage", Journal of Management, Vol. 17, pp. 99-120.

Black, E.L., Carnes, T.A. and Richardson, V.J. (2000), "The market valuation of corporate reputation", Corporate Reputation Review, Vol. 3, pp. 31-42.

Bowen, D.E. (1990), "Interdisciplinary study of service: some progress, some prospects", Journal of Business Research, Vol. 20, pp. 71-9.

Bughin, J.R., Chui, M. and Johnson, B. (2008), “The next step in innovation”, McKinsey Quarterly, No. 4, pp. 112-22.

Carter, S.M. and Ruefli, T.W. (2006), "Intra-industry reputation dynamics under a resource-based framework: assessing the durability factor”, Corporate Reputation Review, Vol. 9, pp. 3-25.

Chesbrough, H.W. (2003a), Open Innovation: The New Imperative for Creating and Profiting from Technology, Harvard Business School Press, Cambridge, MA.

Chesbrough, H.W. (2003b), “The era of open innovation”, MIT Sloan Management Review, Vol. 44 No. 3, pp. 35-41.

Collins, L. (2007), "Embedding innovation into the firm", Research Technology Management, Vol. 50 No. 2, pp. 5-6.

Echols, A. and Tsai, W. (2005), "Niche and performance: the moderating role of network embeddedness", Strategic Management Journal, Vol. 26, pp. 219-38.

Enkel, E., Gassman, O. and Chesbrough, H. (2009), "Open R\&D and open innovation: exploring the phenomenon”, R\&D Management, Vol. 39, pp. 311-6.

Flavian, C. and Guinaliu, M. (2005), "The influence of virtual communities on distribution strategies in the internet", International Journal of Retail Distribution Management, Vol. 33, pp. 405-25.

Fleming, L. and Waguespack, D.M. (2007), "Brokerage, boundary spanning, and leadership in open innovation communities", Organization Science, Vol. 18, pp. 165-83.

Fuller, J., Matzler, K. and Hoppe, M. (2008), "Brand community members as a source of innovation”, Journal of Product Innovation Management, Vol. 25, pp. 608-19.

Goel, R.K. and Hsieh, E.W.T. (2002), "Internet growth and economic theory", Netnomics, Vol. 4, pp. 221-5.

Graham, M.E. and Bansal, P. (2007), “Consumers' willingness to pay for corporate reputation: the context of airline companies", Corporate Reputation Review, Vol. 10, pp. 189-200.

Grant, R.M. (1991), "The resource-based theory of competitive advantage: implications for strategy formulation", California Management Review, Vol. 33 No. 3, pp. 114-35.

Gregory, J.R. (1998), "Does corporate reputation provide a cushion to companies facing market volatility? Some supportive evidence”, Corporate Reputation Review, Vol. 1, pp. 288-90.

Gunter, L. (2002), “The need for speed”, Boeing Frontiers, available at: www.boeing.com/news/ frontiers/archive/2002/july/i_ca2.html

Hall, R. (1992), “The strategic analysis of intangible resources”, Strategic Management Journal, Vol. 13, pp. 135-44. 
Hall, R. (1993), "A framework linking intangible resources and capabilities to sustainable competitive advantage", Strategic Management Journal, Vol. 14, pp. 607-18.

Hamm, S. (2007), "Children of the web”, Business Week, 2 July, pp. 50-8.

Howe, J. (2006), "Your web, your way", Time, 25 December-1 January, pp. 40-1.

Kandampully, J. (2003), "B2B relationships and networks in the internet age", Management Decision, Vol. 41, pp. 443-51.

Karakaya, F. (2002), "Barriers to entry in industrial markets", Journal of Business and Industrial Marketing, Vol. 17, pp. 379-88.

Karakaya, F. and Stahl, M.J. (1989), "Barriers to entry and market entry decisions in consumer goods and industrial goods markets”, Journal of Marketing, Vol. 53 No. 2, pp. 80-91.

Lamarca, R. (2006), “The free range”, Mechanical Engineering Design, Vol. 128 No. 3, pp. 26-9.

Laursten, K. and Salter, A. (2006), "Open for innovation: the role of openness in explaining innovation performance among UK manufacturing firms", Strategic Management Journal, Vol. 27, pp. 131-50.

Lieberman, M.B. (1987), "The learning curve, diffusion and competitive strategy", Strategic Management Journal, Vol. 8, pp. 441-52.

Macher, J.T. and Boerner, C.S. (2006), "Experience and scale and scope economies: trade-offs and performance in development”, Strategic Management Journal, Vol. 27, pp. 845-65.

Mahoney, J.T. and Pandian, R.J. (1992), "The resource-based view within the conversation of strategic management”, Strategic Management Journal, Vol. 13, pp. 363-80.

Marshall, B.V. (1967), Comprehensive Economics: Descriptive, Theoretical, and Applied, Longman, London.

Mitsch, R.A. (1990), “Three roads to innovation”, The Journal of Business Strategy, Vol. 11 No. 5, pp. 18-21.

Nooteboom, B. (2000), "Institutions and forms of coordination in innovation systems", Organization Studies, Vol. 21, pp. 915-39.

Ogawa, S. and Pillar, F.T. (2006), "Reducing the risks of new product development", Sloan Management Review, Vol. 47 No. 2, pp. 65-71.

Peteraf, M.A. (1993), "The cornerstones of competitive advantage: a resource-based view", Strategic Management Journal, Vol. 14, pp. 179-91.

Porter, M.E. (1980), Competitive Strategy: Techniques for Analyzing Industries and Competitors, The Free Press, New York, NY.

Porter, M.E. (2001), “Strategy and the internet”, Harvard Business Review, Vol. 79 No. 3, pp. 63-78.

Raasch, C., Herstatt, C. and Balka, K. (2009), "On the open design of tangible goods", R\&D Management, Vol. 39, pp. 382-93.

Rodan, S. and Galunic, C. (2004), "More than network structure: how knowledge heterogeneity influences managerial performance and innovativeness", Strategic Management Journal, Vol. 25, pp. 541-652.

RTM (2007), “Implementing open innovation”, Research Technology Management, March-April, pp. 21-4.

Sawhney, M. and Prandelli, E. (2000), "Communities of creation: managing distributed innovation in turbulent markets", California Management Review, Vol. 42 No. 4, pp. 24-54.

Schilling, M.A. and Phelps, C.C. (2007), "Interfirm collaboration networks: the impact of large-scale network structure on firm innovation”, Management Science, Vol. 53, pp. 1113-26. 
Steier, L. and Greenwood, R. (2000), "Entrepreneurship and the evolution of angel financial networks", Organization Studies, Vol. 21, pp. 163-92.

Treacy, M. and Wiersema, F. (1995), The Discipline of Market Leaders: Choose your Customers, Narrow your Focus, Dominate your Market, Addison-Wesley Publishing, Reading, MA.

Tsai, W. (2001), "Knowledge transfer in intraorganizational networks: effects of network position and absorptive capacity on business unit innovation and performance", Strategic Management Journal, Vol. 44, pp. 996-1004.

Ulhoi, J.P. (2004), “Open source development: a hybrid in innovation and management theory", Management Decision, Vol. 42, pp. 1095-114.

Veugelers, R. (1997), "Internal R\&D expenditures and external technology sourcing”, Research Policy, Vol. 26, pp. 303-16.

Wind, Y. (2006), "Blurring the lines: is there a need to rethink industrial marketing?", Journal of Business and Industrial Marketing, Vol. 21, pp. 474-81.

\section{Further reading}

Feldman, S.P. (1988), "How organizational culture can affect innovation", Organizational Dynamics, Vol. 17, pp. 57-68.

Preece, J. (2000), Online Communities - Designing Usability, Supporting Sociability, John Wiley and Sons, Chichester.

Post-print standardized by MSL Academic Endeavors, the imprint of the Michael Schwartz Library at Cleveland State University, 